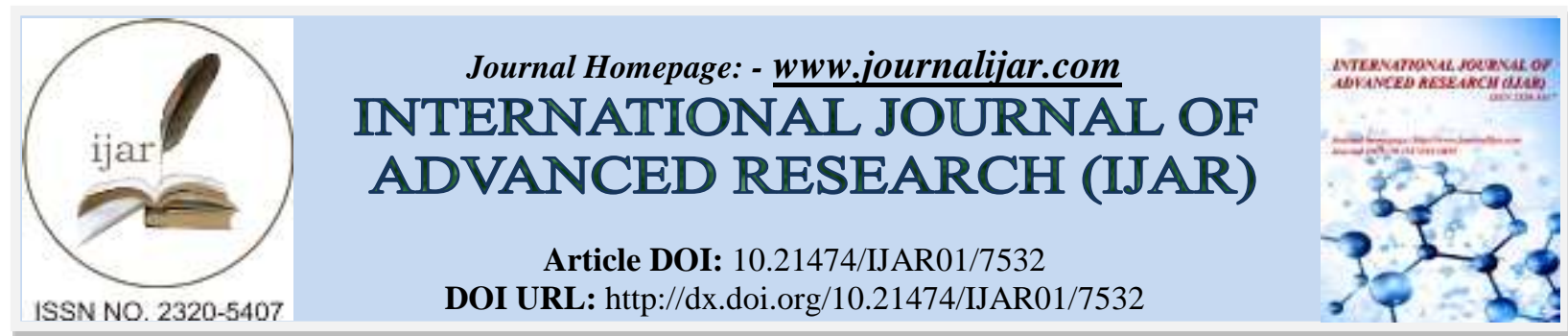

RESEARCH ARTICLE

\title{
ISOLATION, CULTURE AND MORPHOLOGICAL CHARACTERIZATION OF MICROCYSTIS SP TOXIC STRAIN FROM THE TACUARY RESERVOIR.
}

Victoria López Pereira ${ }^{1}$ and Estelvina Rodríguez Portillo ${ }^{2}$.

1. Postgraduate School, National University of Itapúa, 6000, Encarnación, Paraguay.

2. Research Department, Faculty of Science and Technology, National University of Itapúa, 6000, Encarnación, Paraguay.

\section{Manuscript Info}

Manuscript History

Received: 11 June 2018

Final Accepted: 13 July 2018

Published: August 2018

Keywords:-

Microcystis, isolation, culture, cell density, growth rate.

\section{Abstract}

It was studied the growth of the cyanobacterium Microcystis sp. isolated from algal blooms of the Tacuary reservoir. The cultivation was performed in triplicate BG11 medium, average temperature of $25 \pm$ $3^{\circ} \mathrm{C}, 0.8086 \mu \mathrm{mol} \cdot \mathrm{s}^{-1} \cdot \mathrm{m}^{-2}$, with a photoperiod of $14: 10, \mathrm{pH}$ of 7.10 and daily stirring. Isolation was performed by means of the pipette method and sequential dilutions. The isolated culture revealed a maximum growth rate of 0.357 days -1 and minimum of 0.12 day -1 on average doubling time of 4.124 days. During the analysis, the strain increased its density through the acceleration and exponential phases. It reflects in a short time that the strain is conserved with a high rate of cell evolution under controlled conditions; consequently, it contributes to the comprehension of the phenomenon behavior for its management or environmental control.

Copy Right, IJAR, 2018,. All rights reserved.

\section{Introduction:-}

Microcystis aeruginosa populations are fundamental in lakes or reservoirs with lentic characteristics, their existence suggests a risk to both, the ecosystem and human health or sanitation (Watanabe, Park and Watanabe, 1994). The effects of toxic algal blooms in reservoirs, could lead to permanent impacts to aquatic ecosystem for being lentic and with a short time return. There are elements that encourage to the dominance or expansion of the rate of growth in lakes and reservoirs such as temperature, irradiance, nutrients (Paerl and Huisman, 2008, Robarts and Zohary, 1987). Nevertheless, some studies have agreed that the rise of temperature could extent eutrophication and cyanobacterial blooms by increasing the growth rate (Rouco et al., 2011, Gianuzzi et al., 2016; Reinolds, 2006). Likewise, the expansion of the growth rate induces to increased production of the species toxins ( $\mathrm{Li}$ et al., 2013, Rapala et al.,1997).

Since 2013, the Tacuary reservoir has recorded cyanobacteria algal blooms on both sides of the river, they have presented a dominance of the species Microcystis $s p$. which contributes to a sanitary and conservational risk due to the toxic characteristics of the species.

Considering what stated above, the objective of the study was to analyse the environmental conditions of the autochthonous specie isolated from the nature to contribute with knowledge of the algal blooms. 


\section{Methods:-}

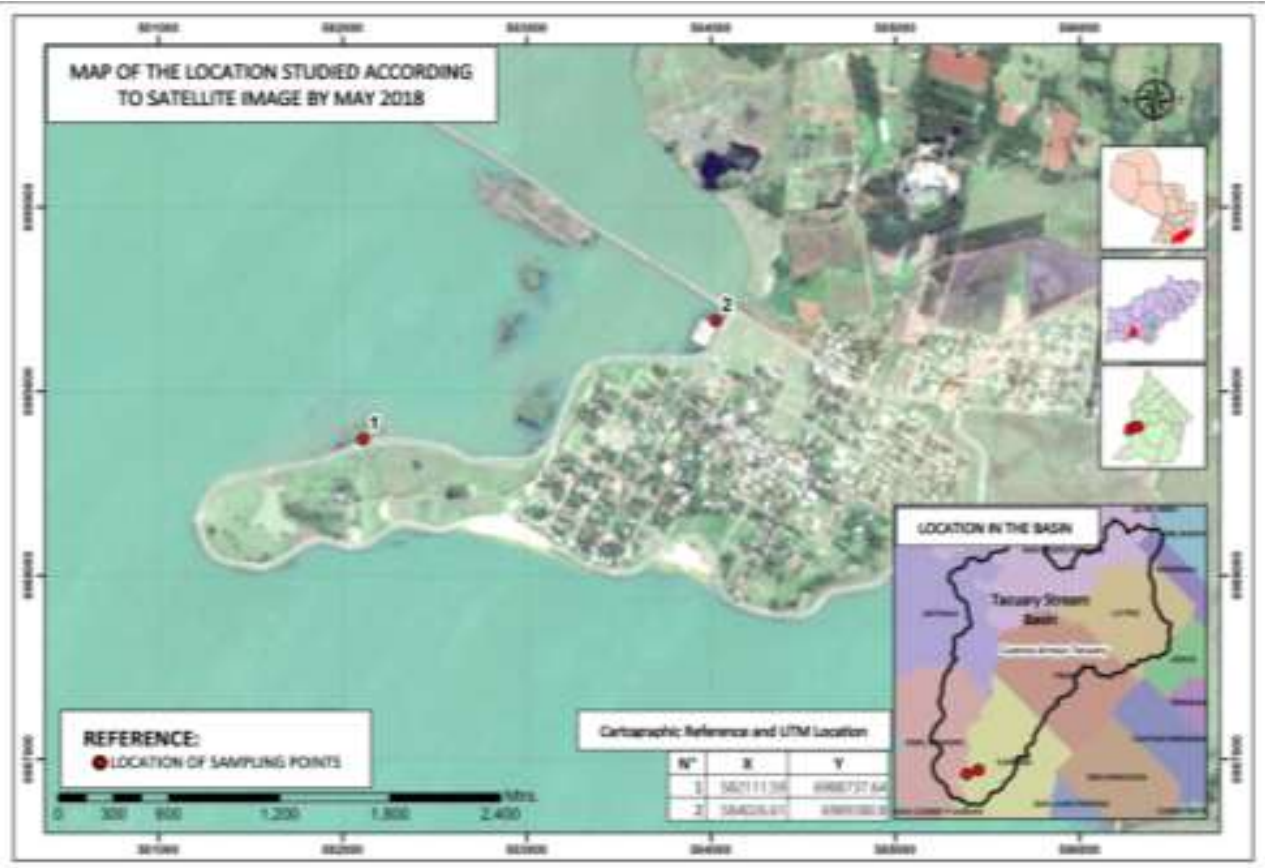

Figure 1:- Location of the sampling points in the Tacuary resevoir.

Cyanobacteria Microcystis aeruginosa was isolated from the Tacuary reservoir ( $27^{\circ} 13^{\prime} 18.49^{\prime \prime}, 56^{\circ} 10^{\prime} 15.40$ "), this reservoir is located in farming regions and flooded forests, besides it collects effluents from swine and rice production of the area, through the streams. It has an extension of $1029.88 \mathrm{~km}^{2}$, the sampling regions have an average in depth of 2.5 meters and during the year the $\mathrm{pH}$ had a range between 8.2 meters and 7.1 meters. Samples were taken at two points of the reservoir, it was performed analysis of physicochemical parameters in situ, such as $\mathrm{pH}$, dissolved oxygen, conductivity, total dissolved solids and temperature.

The documentation was performed considering the taxonomic keys by Anagnostidis and Komárek (1999).

For this study,BG11 was used as culture medium (Allen 1968, Allen and Stainer 1968, Rippka et al., 1979), the pH was adjusted to 7.1 and sterilized in an autoclave at $1 \mathrm{~atm}$ during $15 \mathrm{~min}$. The components prepared in 1 liter were NaNO3, K2HPO4.3H2O, MgSO4.7H2O, CaCl2. 2H2O, citric acid, ferric ammonium citrate, MgNa2EDTA.H2O, $\mathrm{Na} 2 \mathrm{CO} 3$, and trace metals such as $\mathrm{H} 3 \mathrm{BO} 3, \mathrm{MnCl} 2.4 \mathrm{H} 2 \mathrm{O}, \mathrm{ZnSO} 4.7 \mathrm{H} 2 \mathrm{O}, \mathrm{Na} 2 \mathrm{MoO} 4.2 \mathrm{H} 2 \mathrm{O}$, CuSO $4.5 \mathrm{H} 2 \mathrm{O}$, Co (NO3) $2.6 \mathrm{H} 2 \mathrm{O}$.

\section{Morphological characterization:-}

The morphological characterization of Microcystis $\boldsymbol{s} \boldsymbol{p}$ cell. was completed using an optical microscope (AXLLabovision-Eglas) at a resolution of 40x and 100x $(10 \mu \mathrm{m})$ and considering the taxonomic guide by Komárek and Anagnostidis (1999).

\section{Sampling, isolation and purification of strains.}

The phytoplankton material gathered directly with a 125 -micron net was conserved in $500 \mathrm{ml}$ plastic bottles, with water from the reservoir, which were prepared to transfer to the laboratory. The material collected was looked at under an AXL-Labovision-Eglass optical microscope at 10x, 40x and 100x.

For the isolation of Microcystis sp. the pipette and successive dilutions method were performed to isolate colonial or filamentous forms (Andersen and Kawachi, 2005), following the isolation protocol of Jacinavicius et al., (2013).

The samples were placed in Erlenmeyer of $500 \mathrm{ml}$, from which 1 aliquot of $1 \mathrm{ml}$ of material was taken and set on a slide for observation in the optical microscope, where once the cell of Microcystis sp. was isolated by capillarity to be placed in Petri dishes with $1 \mathrm{ml}$ of distilled water, for triple washing of contaminating material. 
The isolated cells were placed in inoculated test tubes with $5 \mathrm{ml}$ of the BG11 culture medium (Rippka et al., 1979). Fifteen replications were performed for seven days and then its pealing was performed at $500 \mathrm{ml}$. for 5 days, and continuously to $1000 \mathrm{ml}$.

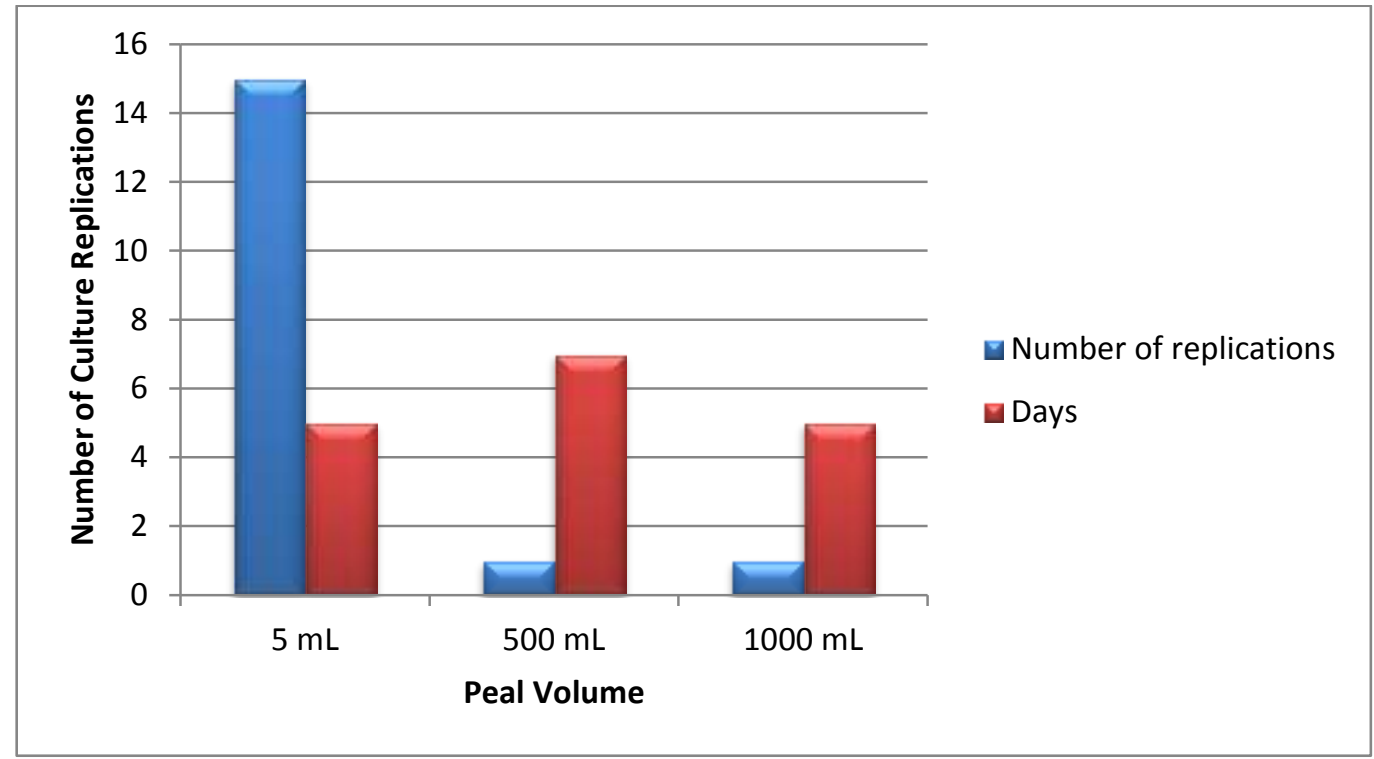

Figure 2:- Isolated culture peal sequence.

\section{Environmental conditions of cultivation:-}

The strain was maintained in Erlenmeyer with 1 liter of the BG11 medium, to which $500 \mathrm{~mL}$ of inoculum was added, under temperature conditions of $25 \pm 3{ }^{\circ} \mathrm{C}$, luminance of $62.2 \mathrm{Lm} / \mathrm{m} 2$ with LED fluorescent tubes and incandescent bulbs of $100 \mathrm{~W}$, photoperiod of 14:10 room temperature, as well as manual shaking for three times per day.

\section{Growing count:-}

To estimate cell growth, it was taken $1 \mathrm{ml}$ of the $1000 \mathrm{ml}$, and the cell count was performed in a Neubauer chamber for a five days period after the counting protocol (Arredondo and Voltolina, 2007), applying the formula:

Cell concentration: $\mathrm{Nx} 10000 / \mathrm{N}^{\circ}$ of frames; (equation 1)

Where: $\mathrm{N}$ is the number of cells counted in the four large squares

The growth curve was achieved by calculating the ordinary logarithm of the obtained cell density (Tortora et al., 2007)

The growth rate (day -1), was estimated using the following formula (Guillard, 1973)

$\mu=\ln (\mathrm{X} 2 / \mathrm{X} 1) /(\mathrm{t} 2-\mathrm{t} 1)$ (equation 2)

Where:

$\mu$ is the growth rate $\mathrm{x} 0$ and $\mathrm{x} 1$ is the initial and final cell concentration, $\mathrm{t} 0$ and $\mathrm{t} 1$ the initial and final time.

\section{Duplication time:-}

$\operatorname{tg}=\ln 2 / \mu \mathrm{e}=0.693 / \mu \mathrm{e}($ equation 3)

\section{Results}

\section{Description of the study area:-}

The physicochemical variables of the water collected (table 1), reveal that during the sampling dates the temperature oscillated between $26.9-28.9^{\circ} \mathrm{C}$, it presents characteristics with alkaline trend and its $\mathrm{pH}$ oscillates from7.63-7.43, the dissolved oxygen $7.65 \mathrm{mg} / \mathrm{L}-6.66 \mathrm{mg} / \mathrm{L}$, showing good oxygenation and the mean conductivity was 73.3 $\mu \mathrm{S} / \mathrm{cm}$ and $75.3 \mu \mathrm{S} / \mathrm{cm}$ (Table 1$)$. 


\begin{tabular}{|l|l|l|l|l|l|}
\hline Sampling Points & OD $(\mathbf{m g} / \mathbf{L})$ & Conductivity $(\boldsymbol{\mu S} / \mathbf{c m})$ & TDS $(\mathbf{m g} / \mathbf{L})$ & Temperaturh $\left({ }^{\circ} \mathbf{C}\right)$ & $\mathbf{p H}$ \\
\hline 1 & 7,65 & 73,3 & 39,2 & 26,9 & 7,63 \\
\hline 2 & 6,66 & 75,3 & 40,4 & 28,9 & 7,43 \\
\hline
\end{tabular}

Table 1:- Physicochemical variables of water at sampling points

The direct samples contained higher dominance of Microcystis aeruginosa, colonies comparing with the net samples.

Oder: Chroococcales

Species: Microcystis aeruginosa (Kuntzing) Kuntzing 1866
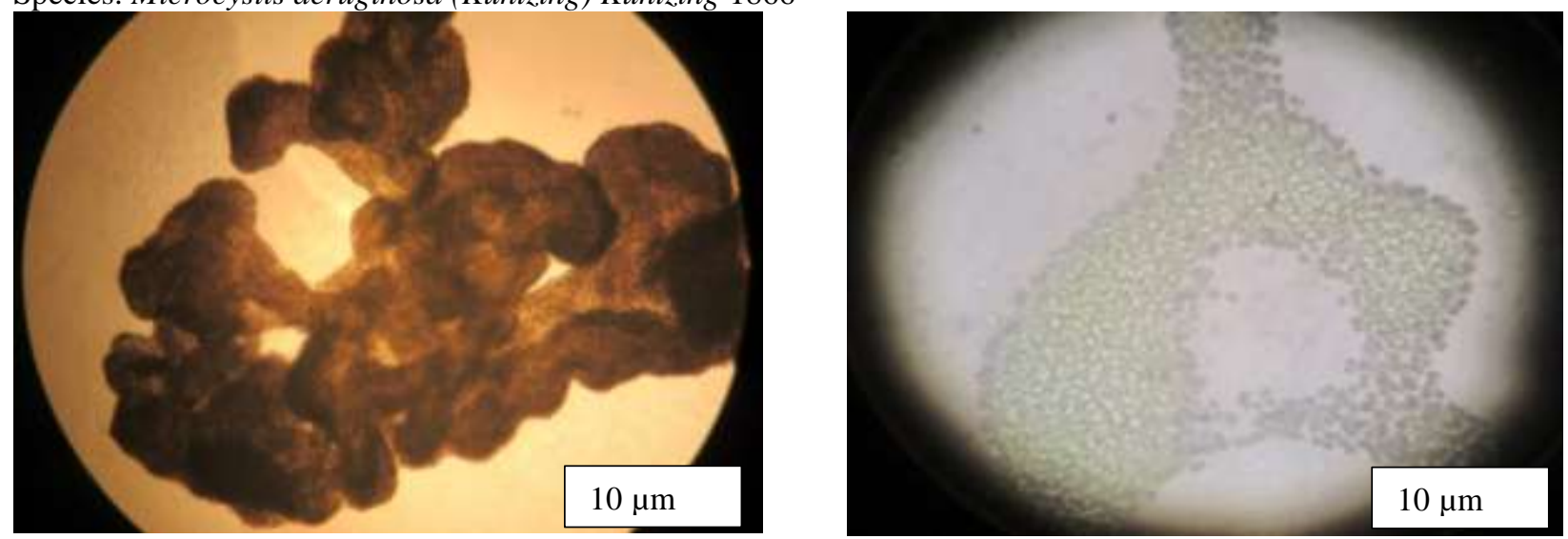

Figure 3:- Microcystis aeruginosa formation in the Tacuary reservoir

The M. aeruginosa species (Figure 1) is a cyanobacterium from the Chroococcal order that produces irregular colonies that can measure $352 \mu \mathrm{m}$ in average long (min: 55.0; max: 650) and $402 \mu \mathrm{m}$ in width (min: 55.0 ; max: 725). Cells are spherical to hemispherical, with average sizes of $4.9 \mu \mathrm{m}$ (min: 3.0; máx: 7.0), after cell division. (Komárek and Anagnostidis, 1999). Lobulated, globose and generally claustrated, diffuse and transparent mucilage colonies, that far surpasses the limit of the cells. Spherical and dark cells, due to the excessive density of aerosols, focused in the center of the colonies. (Bonilla et al., 2009).

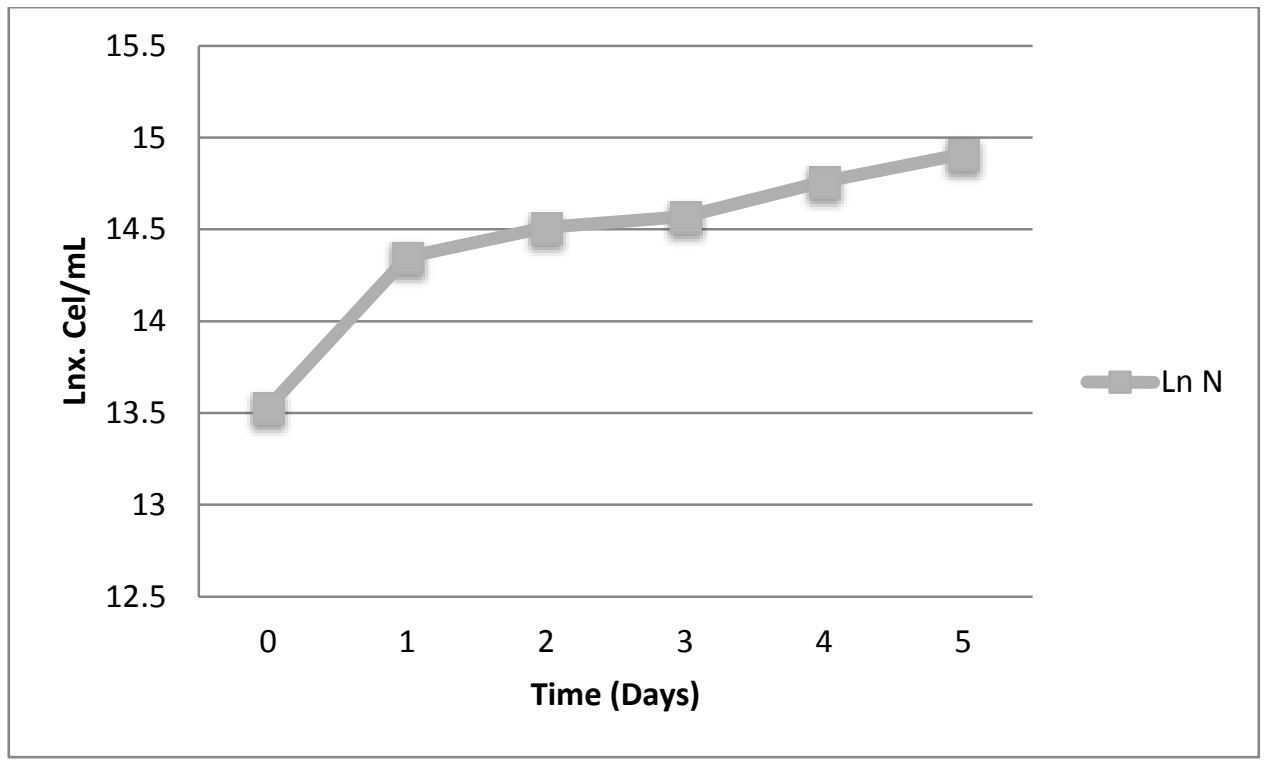

Figure 4:- Microcystis aeruginosa growing curve 


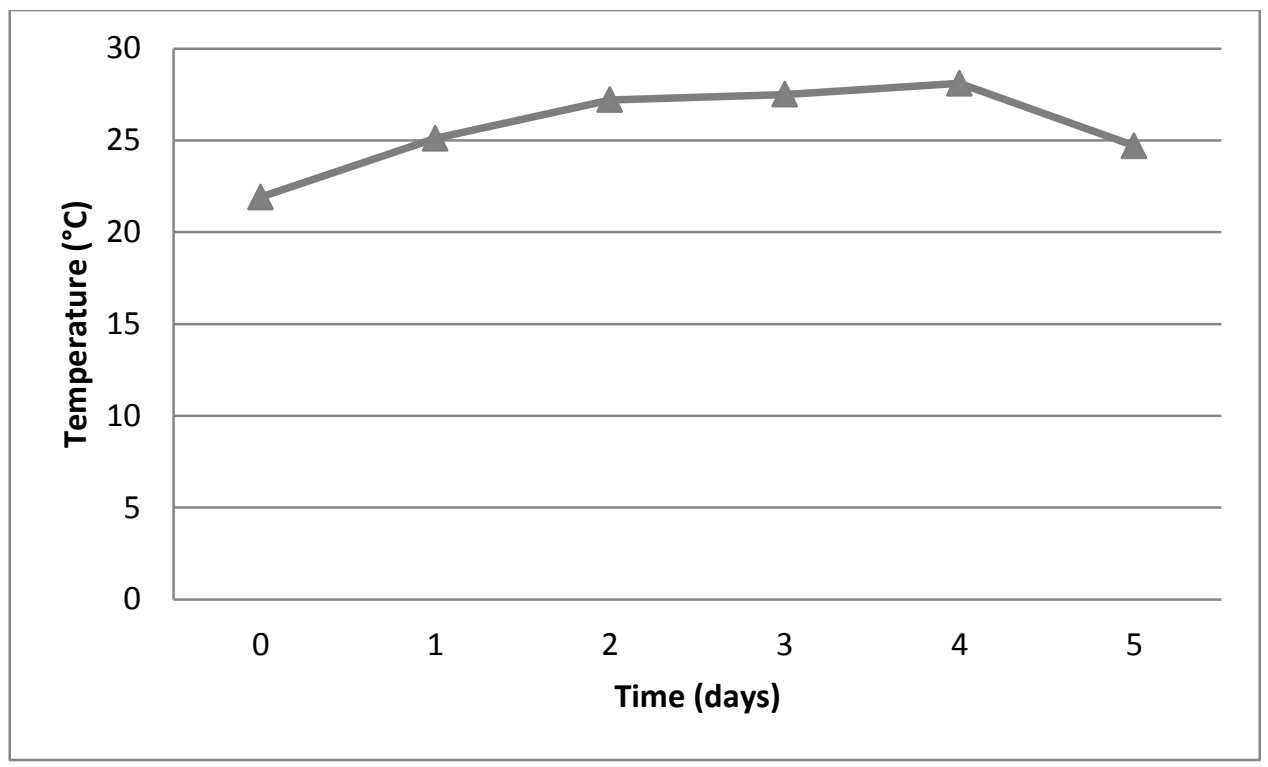

Figure 5:- Culture temperature curve

The culture temperature was maintained at an average of $25.7^{\circ} \mathrm{C}$, with a maximum of $28.1^{\circ} \mathrm{C}$ and a minimum of $21.9^{\circ} \mathrm{C}$ (Fig.5). The growing rate of Microcystis aeruginosa increased in relation to the $4^{\circ} \mathrm{C}$ increase of the initial temperature.

\begin{tabular}{|l|l|l|l|l|}
\hline Days & Ln N & $\boldsymbol{\mu}($ day-1) & Td & Temperature $\left({ }^{\circ} \mathbf{C}\right)$ \\
\hline 0 & 13,53 & & & 21,9 \\
\hline 1 & 14,35 & 0,357 & 1,94 & 25,1 \\
\hline 2 & 14,51 & 0,212 & 3,26 & 27,2 \\
\hline 3 & 14,57 & 0,150 & 4,62 & 27,5 \\
\hline 4 & 14,76 & 0,134 & 5,1 & 28,1 \\
\hline 5 & 14,91 & 0,120 & 5,7 & 24,7 \\
\hline
\end{tabular}

Table 2:- Ln of cell concentration, growth rate ( $\mu$ ), Diplication time (Dt), culture temperature of Microcystis aeruginosa $\left({ }^{\circ} \mathrm{C}\right)$

The highest growth rates of Microcystis aeruginosa under experimental environments were from 0.357 day-1 to 25.1 ${ }^{\circ} \mathrm{C}$ with 1.94 days in duplication time on day 1 and 0.212 day- 1 at $27.2^{\circ} \mathrm{C}$. With a minimum range of 0.12 day- 1 to $24.7^{\circ} \mathrm{C}$ on day 5 , with an average of duplication time of 4.124 days (Table 2), no significant growth changes were observed during the other days of experimentation.

Connecting temperature and growth range curves, it was perceived that there was an evident increase with the rise of the initial temperature to 3.2 and $5.3^{\circ} \mathrm{C}$, correspondingly. Conversely, although high temperatures have influenced its growth, a higher increase is not suggested in higher temperatures recorded during the experimental period.

\section{Discussion:-}

Cell count suggested evidence such as cell concentration, intrinsic growth curve and time of duplication of the cell, in which the main environmental factor was temperature. While there are some environmental aspects that influence the growth or appearance of cyanobacteria in natural environments such as high temperatures, high $\mathrm{pH}$, the facility to fix atmospheric nitrogen and irradiation (Paerl and Huisman, 2008, Li et al., 2012).

The growth of the autochthonous Microcystis strain of the Tacuary reservoir was comparable to that reported by Gianuzzi et al., (2016), with growth rates of 0.31 and 0.33 day-1, separately, at $23^{\circ} \mathrm{C}$ and an increase in the range to $29^{\circ} \mathrm{C}$. Hereof, is suggested that temperature has a substantial consequence in the growth range of the species Microcystis, being isolated species of tropical ecosystems; and as it was characterized in the natural environment, with $26^{\circ} \mathrm{C}$ and $28.9^{\circ} \mathrm{C}$, the reservoir conserves a high temperature on an annual average, which reveals that there 
could be a larger presence of blooms of Microcystis sp. This characteristic of the cyanobacterium analyzed suggests a high rate of growth of the same given the mentioned environmental conditions.

What mentioned above is connected to what Forjan et al., (2008) and Robarts et al., (1987) mentioned, on which the optimum temperature for the growth of these blooms is nearly $25^{\circ} \mathrm{C}$. Similarly, studies carried out on blooms of Lake Ypacarai in different seasons have revealed an excessive presence of Microcystis aeruginosa in temperature between $25^{\circ} \mathrm{C}$ to $33^{\circ} \mathrm{C}$, in regular environments (Benitez Rodas, et al., 2017, Rodríguez et al., 2005; Liu, 2011). This is similar to the behavior of the strain in laboratory conditions to those presented in eutrophied lakes. According to Li et al., (2012), at high intensities of light and temperature reach a greater range of specific growth.

The values mentioned were lower than what stated by Lick (2004) who reported values of $\mu$ between 0.52 to 0.54 day-1 at a higher temperature $\left(18{ }^{\circ} \mathrm{C}-32{ }^{\circ} \mathrm{C}\right)$; and 0.44 day- 1 at $25^{\circ} \mathrm{C}$. Watanabe et al., (1985), nevertheless, at temperatures above $25^{\circ} \mathrm{C}$, the analyzed strain declined its growth rate, remaining constant at temperatures between $27.2^{\circ} \mathrm{C}$ and $28.1^{\circ} \mathrm{C}$, a behavior that disagrees from what informed in crops of the species. While Crettaz et al., (2017), documented values of $\mu$ between 0.17 to 0.20 day- 1 at temperatures between 25 and $26^{\circ} \mathrm{C}$, Von Ruckert and Gianni (2004) reported a growth of the species between $0.263 \mu$ and $0.393 \mu$ in experimental conditions, which are associated to those achieved in the Tacuary reservoir strain.

Temperature is one of the most important variables that controls the taxonomic domain in natural environments, operating synergistically with other aspects as mentioned by Robarts et al., (1987). Also, there is a close association between the rate of growth and the production of microcystin by the cells, at high growth rates boosted the production of microcystin in small cells (Long et al., 2001)

Results achieved were similar to the typical colonial cell growth in laboratory with a range of 0.29 day-1 (Li et .al., 2012).

\section{Conclusion:-}

This study demonstrates that under experimental conditions, the species Microcystis aeruginosa native in the Tacuary reservoir revealed a similar growth rate to those developed in eutrophic lakes in natural conditions. It shows an appropriate temperature of $25^{\circ} \mathrm{C}$ and declining the rate at higher temperatures at $27^{\circ} \mathrm{C}$. Therefore, water temperature is a crucial element for cell growth, demonstrating that it can also impact additional processes such as production of toxins. Consequently, it can be predicted blooming of the species given the optimal temperature conditions in interaction with additional environmental elements that affect this process.

\section{Acknowledgments:-}

Special acknowledgments to the National Council of Sciences and Technologies (CONACYT) of Paraguay and the Doctorate in Environmental Management program as well as the incentives program for researcher which made possible this study.

\section{References:-}

1. Benítez, G.A.1; Ávalos, C.; Araujo, C.; Acosta, R.; Escobar, A.;Franco, G.; Astigarraga, O.; Peralta, I. and Cardozo, C. 2016. Influencia de factores ambientales sobre la biodiversidad de cianobacterias en el lago Ypacarai. https://www.researchgate.net/publication/309607815

2. Bonilla, S., 2009. Cianobacterias planctónicas del Uruguay. Manual para la identificación y medidas de monitoreo.Montevideo: UNESCO. PHI-VII (Documento técnico, 16). ISBN: 978-92-9089-138-3.

3. Giannuzzi, L., Krock, B., Minaglia, M. C. C., Rosso, L., Houghton, C., Sedan, D., and Hernando, M. (2016). Growth, toxin production, active oxygen species and catalase activity of Microcystis aeruginosa (Cyanophyceae) exposed to temperature stress. Comparative Biochemistry and Physiology Part C: Toxicology \& Pharmacology, 189, 22-30.

4. Houghton, J.T., Ding, Y., Griggs, D.J., Noguer, M., Van Der Lin-Den, P.J., Dai, X., Maskell, K. and Johnson, C.A. (2001). Climate Change 2001: the Scientific Basis. Cambridge University Press, Cambridge, p. 881.

5. JACINAVICIUS, F. R., Gama Junior, W. A., Azevedo, M. T. P. and SANTANNA, C. (2013). Manual para cultivo de cianobactérias. São Paulo: Secretaria do Meio Ambiente.

6. Komárek, J. (2003) Coccoid and colonial cyanobacteria. In: Wehr, JD.; Sheath, RG., editors. Freshwater Algae of North America. San Diego, CA: Academic Press; p. 59-116. 
7. Komárek, J. and K. Anagnostidis (1999). Cyanoprokaryota 1 Teil: Chroococcales. H. Etts, G. Gärtner, H. Heynig and D. Mollenhauer (Eds.) Jena, Gustav Fischer: 548pp.

8. Li, M.; Zhu, W.; Gao, L. and Lu, L (2013). Changes in extracellular polysaccharide content and morphology of Microcystis aeruginosa at different specific growth rates. J. Appl. Phycol., 25, 1023-1030

9. Liu Xia, Lu Xiaohua and Chen Yuwei (2011), The effects of temperature and nutrient ratios on Microcystis blooms in Lake Taihu, China: An 11-year investigation, Harmful Algae, Volume 10, Issue 3,2011, Pages 337343,ISSN 1568-9883,https://doi.org/10.1016/j.hal.2010.12.002

10. Lick. (2004). Simultaneous changes in cell quotas of microcystin, chlorophyll a, protein and carbohydrate during different growth phases of a batch culture experiment with Microcystis aeruginosa. Journal Of Plankton Research, 26 (7): 727-736.

11. Long, B. M., Jones, G. J., and Orr, P. T. (2001). Cellular Microcystin Content in N-Limited Microcystis aeruginosa Can Be Predicted from Growth Rate. Applied and Environmental Microbiology, 67(1), 278-283. http://doi.org/10.1128/AEM.67.1.278-283.2001

12. Paerl, H.W. and Huisman, J. (2008). Blooms like it hot. Science 320, 57-58.

13. Phelan, R. R. and Downing, T. G. (2011), A GROWTH ADVANTAGE FOR MICROCYSTIN PRODUCTION BY MICROCYSTIS PCC7806 UNDER HIGH LIGHT. Journal of Phycology, 47: 1241-1246. doi:10.1111/j.1529-8817.2011.01056.x

14. Rapala, J., Sivonen, K., Lyra, C. and Niemelä, S.I. (1997). Variation of microcystins, cyanobacterial hepatotoxins, in Anabaena spp. as a function of growth stimuli. Appl. Environ. Microbiol. 63, 2206-2212

15. Reynolds, C.S. (2006a). The Ecology of Phytoplankton (Ecology, Biodiversity and Conservation). Cambridge University Press, Cambridge, UK.

16. Rittersburch, B. (1988) Estudio limnológico del Lago Ypacarai Rev. Asoc. Cienc. Nat. Litoral (19) 1: 11-26

17. Rippka, R., Deruells, J. and Waterburry, J.B. (1979). Generic assignments, strain histories and properties of pure cultures of cyanobacteria. J. Gen. Microbiol. 111, 1-61.

18. Rouco, M., López-Rodas, V., Flores-Moya, A., and Costas, E. (2011). Evolutionary changes in growth rate and toxin production in the cyanobacterium Microcystis aeruginosa under a scenario of eutrophication and temperature increase. Microbial Ecology, 62(2), 265-273. doi:10.1007/s00248-011-9804-0

19. Robarts Richard D. and Zohary Tamar (1987) Temperature effects on photosynthetic capacity, respiration, and growth rates of bloom-forming cyanobacteria, New Zealand Journal of Marine and Freshwater Research, 21:3, 391-399, DOI: 10.1080/00288330.1987.9516235

20. Rodríguez M. I, Busso F., Bustamante M.A., Ruibal Conti A., Ruiz M. and Angelaccio C.M. (2005) Floraciones de algas en el embalse San Roque. XX Congreso Nacional del Agua y III simposio de Recursos Hídricos del Cono Sur. Mendoza, Argentina

21. Tortora, G. J., Funke, B. R. and Case, C. L. (2007). Introducción a la Microbiología. Ed. Médica Panamericana

22. Von Rückert G and Giani A (2004) Effect of nitrate and ammonium on the growth and protein concentration of Microcystis viridis Lemmermann (Cyanobacteria). Rev Bras Bot 27: 325-331.

23. Watanabe M.F, Park H.D. and Watanabe M. (2017) Compositions of Microcystis species and heptapeptide toxins, SIL Proceedings, 1922-2010, 25:4, 2226-2229, DOI: 10.1080/03680770.1992.11900602

24. Watanabe, M. F. and Oishi, S. (1985). Effects of Environmental Factors on Toxicity of a Cyanobacterium (Microcystis aeruginosa) under Culture Conditions. Applied and Environmental Microbiology, 49(5), 13421344.

25. Wilson AE, Wilson WA and Hay ME. (2006). Intraspecific variation in growth and morphology of the bloom forming cyanobacterium Microcystis aeruginosa. Applied and Environmental Microbiology 72: 7386-7389. 